\title{
Application of Automatic TIG Welding for Yamal LNG Process Piping Fabrication
}

\author{
Zhijian Wang ${ }^{1, ~ *, ~ Y a n y a n ~} \mathrm{Li}^{1}$, Chiaming Chang ${ }^{2}$ \\ ${ }^{1}$ China National Petroleum Offshore Engineering Co, Ltd, Qingdao, China \\ ${ }^{2}$ Research and Development Department, Kuanuang Tai Metal Industrial Co., Ltd, Tainan, Taiwan
}

Email address:

wangzhijian213@163.com (Zhijian Wang), cmchang@kuangtai.com (Chiaming Chang)

${ }^{*}$ Corresponding author

\section{To cite this article:}

Zhijian Wang, Yanyan Li, Chiaming Chang. Application of Automatic TIG Welding for Yamal LNG Process Piping Fabrication. International Journal of Oil, Gas and Coal Engineering. Vol. 6, No. 4, 2018, pp. 44-49. doi: 10.11648/j.ogce.20180604.11

Received: June 5, 2018; Accepted: June 26, 2018; Published: July 24, 2018

\begin{abstract}
The representative materials, used in Russian Yamal LNG project, are ASTM A333 Gr.6 (low temperature carbon steel, designed temperature of $-50^{\circ} \mathrm{C}$ ) and ASTM A312/A358 TP304/304L (austenitic stainless steel, designed temperature of $196^{\circ} \mathrm{C}$ ). The welding technical specification demands TIG (Tungsten Inert Gas) welding for root welding of piping. This project adopts the construction way of prefabrication in Qingdao and assembly in Russian. Therefore, high construction accuracy is required. This article introduces the LNG process piping welding by automatic TIG welding which contains welding process design, welding process parameters, test and analysis of weld mechanical property and advantage analysis of TIG welding as well. In this project, the automatic and high efficient TIG welding is used for the root welding and hot welding of low temperature carbon steel and austenitic stainless steel piping. The result shows that the mechanical properties of weld metals meet the requirements of LNG project technical specification and code ASME B31.3. The efficiency of automatic TIG welding increases 2 times compared with conventional manual TIG welding. The automatic TIG welding improves and optimizes the quality and construction progress of the LNG project process piping.
\end{abstract}

Keywords: Yamal in Russian, LNG Project, Process Piping, Automatic TIG Welding

\section{Introduction}

China National Petroleum Offshore Engineering CO., LTD contracts Russian Yamal LNG project. The Project is based on the Yamal Peninsula, above the Arctic Circle, and utilizes the resources of the South Tambey Field. This natural gas liquefaction plant has usually been frozen for nine months a year with the minimum temperature as low as $-50^{\circ} \mathrm{C}$. The engineering volume of Yamal project divides into 169 modules which consist of 50,000 tons steel structure and $190,000 \mathrm{~m}$ process piping. The size of process piping is between 0.5 and 72 inch. Work volume of welding is 237,000 DN (welding equivalent). The main work of this project contains the structure of PAR and prefabrication of process piping. The length of prefabricated process piping is 20 to 44 $\mathrm{m}$. Especially, LNG piping (service temperature is $-169^{\circ} \mathrm{C}$ ) needs cryogenic insulation. The project adopts the construction way of prefabrication in Qingdao and assembly in Russian. Therefore, high construction accuracy is needed. Process piping is categorized into low temperature steel and austenite stainless steel. The popular material of low temperature carbon steel is ASTM A333 Gr.6 (designed temperature of $-50^{\circ} \mathrm{C}$ ). The representative material of austenitic stainless steel is ASTM A312/A358 TP304/304L (designed temperature of $-196^{\circ} \mathrm{C}$ ).

The Job specification of Yamal Project demands that TIG welding must be used for the root pass welding [1]. The manual TIG welding is usually used for root pass and hot pass of conventional LNG process piping. This method is low efficient and needs good skilled welders. To improve the efficiency and quality of root pass and hot pass welding, the construction of process piping divides to two parts (prefabrication in workshop and installation in construction site). The automatic TIG welding is used in prefabrication and manual TIG welding is used in installation in construction. 


\section{Automatic TIG Welding}

Automatic TIG welding is carried out by automatic wire feeding, torch oscillation and workpiece rotation. Theoretically, the whole welding process is not influenced by human and processes high welding speed and good quality of weld metals.

Automatic TIG welding system consists of power source, TIG torch, cantilever welding machine, wire feeding system, cooling system, and cartridge pipe drive. The features of this process are following:

(1) Arc length control (ALC):

The unstable arc or short circuit in automatic TIG welding process usually happens when the arc length is not consistent. Unstable arc length is caused by the varied distance between tungsten electrode and workpiece. Varied distance results from the tolerances of workpiece's ovality and groove machining. The unstable arc and short circuit influence the quality of weld metals. ALC system can control and stabilize the arc length to obtain stable arc length.

(2) Oscillation control:

Oscillation means the movement direction of torch is perpendicular to the welding direction during torch travel or workpiece rotation process. When the width of weld bead exceeds certain value, using high welding current is not able to fuse well. Oscillation is able to ensure the well-fusion because the torch dwells at side of weld bead.

(3) Wire Feeding System:

Wire is fed automatically into the arc and fused to the weld pool in automatic TIG welding. The best position of fed wire is ahead or behind of the weld pool. The angle of wire feeding is an important factor to the quality of weld metal. Too steep angle of wire feeding causes the unstable wire feeding because the wire hits the workpiece to make the tip shaking. Too flat angle of wire feeding makes the control of extension difficult and changes the shape of reverse side of the root pass.

\section{Weldability Analysis of Process Piping}

ASTM A333 Gr.6 and ASTM a350 LF2 CL1 are applied in $-50^{\circ} \mathrm{C}$ environment. The main issue of welding A333 and A350 is how to ensure the toughness at low temperature. Even low temperature carbon steel is good at toughness and plasticity, the reheating process makes the grain growth causing the deterioration of toughness and plasticity. Yamal project demands that the toughness of weld metal exceeds $27 \mathrm{~J}$ at $-50^{\circ} \mathrm{C}$. Therefore, appropriate welding process, welding consumables, welding parameter and heat input are important to meet the requirement of toughness at low temperature.

The toughness of austenitic stainless steel ASTM A312/A358 TP304/304L is slightly decreased with temperature decease. The austenite stainless does not possess brittle-ductile transition behavior. This material can be used in $-196^{\circ} \mathrm{C}$ cryogenic environment. The 8 ferrite has a remarkable effect in decreasing the hot-cracking susceptibility of austenitic stainless steel welds [2]. The ferrite number is controlled to behind $7 \mathrm{FN}$ because the ferrite in austenite stainless steel lowers the toughness at low temperature. Additionally, the HAZ near weld metal precipitates carbides when the temperature of weld metal is between 600 and $800^{\circ} \mathrm{C}$. The precipitation of carbides deteriorates the intergranular corrosion resistance. Hence, the heat input of austenite stainless steel welding need to be controlled strictly to reduce the time of weld metal between 600 and $800^{\circ} \mathrm{C}$ [3-6].

It is essentially needed to study how to replace manual TIG welding with automatic TIG welding based on the welding characteristics of low temperature carbon steel and austenitic stainless steel. Meanwhile, how to guarantee the toughness at low temperature without compromising with the intergranular corrosion resistance of austenitic stainless steel through a precise control of heat input in automatic TIG welding is crucial.

\section{Welding Procedure Qualification}

\subsection{Design of Welding Method}

The automatic TIG welding is applied in root pass and hot pass welding of process piping. The fill pass and cap pass welding use pulse MIG welding and automatic FCAW or SAW to improve the welding efficiency of process piping. The current of automatic TIG welding is higher than that of manual TIG welding. The thickness of weld metal is $1 \mathrm{~mm}$ higher than that of manual TIG welding. The automatic TIG welding needs only 2 pass welding but manual TIG welding needs 3 pass welding. Therefore, the automatic TIG welding performs higher welding efficiency than manual one.

Selection of Welding machine: Automatic TIG welding uses MILLER XMT 450MPa to weld root pass and hot pass. This machine equips with two wire feeders to complete MIG, FCAW and SAW. All welding can put into practice in the same welding machine. The welding efficiency of automatic TIG welding is higher than that of manual TIG welding in root pass and hot pass. The heat input is also controlled to guarantee the quality of weld metal.

\subsection{Base Metal for Welding Procedure Qualification}

The welding specification of LNG process piping is ASME B31.3 and ASME IX. This study is carried out by ASME IX specification. ASTM A333 Gr.6 (Group No.1) and ASTM A350 LF2 CL1 (Group No.2) is used in the welding procedure qualification of low temperature carbon steel piping. TP304/304L is used in the welding procedure qualification of austenitic stainless steel piping. The chemistries and mechanical properties of base metals are shown in Table 1 and Table 2, respectively. 
Table 1. Chemical composition of base metals.

\begin{tabular}{|c|c|c|c|c|c|c|c|c|c|c|c|}
\hline Grade & C & Mn & $\mathbf{P}$ & $\mathbf{S}$ & $\mathbf{S i}$ & $\mathbf{N i}$ & $\mathrm{Cr}$ & Mo & $\mathbf{C u}$ & $\mathbf{C b}$ & $\mathbf{V}$ \\
\hline A333 Gr.6 & 0.3 & $0.29 \sim 1.06$ & 0.025 & 0.025 & $0.10 \mathrm{Min}$. & & & & & & \\
\hline A350 LF2 CL1 & 0.3 & $0.60 \sim 1.35$ & 0.035 & 0.04 & $0.15 \sim 0.40$ & 0.4 & 0.3 & 0.12 & 0.4 & 0.02 & 0.08 \\
\hline $304 \mathrm{~L}$ & 0.035 & 2.0 & 0.045 & 0.030 & 1.0 & $8 \sim 13$ & $18 \sim 20$ & & & & \\
\hline
\end{tabular}

Table 2. Mechanical properties of base metals.

\begin{tabular}{lllll}
\hline Grade & Y.S./MPa & T.S./MPa & $\boldsymbol{E . L . / \%}$ & $\boldsymbol{A v e}_{\mathbf{J}} \mathbf{J}\left(-\mathbf{4 5} \mathbf{C}^{\circ} \mathbf{)}\right.$ \\
\hline A333 Gr.6 & 214 Min. & 415 Min. & 30 & 18.5 \\
A350 LF2 CL1 & 240 Min. & $415 \sim 585$ & 30 & 17.6 \\
304L & 170 Min. & 485 Min. & 35 & 27 \\
\hline
\end{tabular}

\subsection{Welding Parameters}

\subsubsection{Low Temperature Carbon Steel Piping}

The temperature design of low temperature carbon steel piping is $-50^{\circ} \mathrm{C}$ depending on the demand of LNG project. The welding consumables of TIG + FCAW are KM-80Ni1 (ER80S-Ni1)/KFX-81K2 (E81T1-K2). The welding consumables of TIG+SAW are KM-80Ni1 (ER80S-Ni1) and PREMIER WELD Ni1K+PREMOER 8500. Two welding processes meet the toughness requirement of $27 \mathrm{~J}$ min. at $-60^{\circ} \mathrm{C}$. The design and parameter of welding procedure qualification for low temperature carbon steel is shown in Table 3 and Table 4, respectively.

Table 3. Design for welding procedure qualification for low carbon steel.

\begin{tabular}{lllllll}
\hline WPS No. & Thickness of piping $(\mathbf{m m})$ & Groove & Welding process & Welding consumables & Shielding gas & Heat treatment \\
\hline $01 / 18$ & $11.6 / 5.8$ & V type & GTAW/FCAW & ER80S-Ni1/E81T1-K2C & $100 \% A r / 100 \% \mathrm{CO}_{2}$ \\
02 & 11.6 & V type & GTAW/SAW & ER80S-Ni1/ENi1K-Ni1 & $100 \%$ Ar/-- & \\
03 & 12.7 & V type & GTAW/SAW & ER80S-Ni1/ENi1K-Ni1 & $100 \%$ Ar/-- & PWHT \\
\hline
\end{tabular}

Table 4. Welding parameters for low carbon steel.

\begin{tabular}{|c|c|c|c|c|c|c|c|c|c|}
\hline WPS. No. & Pass & $\begin{array}{l}\text { Welding } \\
\text { process }\end{array}$ & $\begin{array}{l}\text { Welding } \\
\text { consumables }\end{array}$ & $\begin{array}{l}\text { Wire size } \\
(\mathrm{mm})\end{array}$ & Polarity & Current (A) & Voltage (V) & $\begin{array}{l}\text { Speed } \\
\left(\mathrm{mm} \cdot \mathrm{min}^{-1}\right)\end{array}$ & $\begin{array}{l}\text { Gas } \\
\text { flow } /\left(L \cdot \min ^{-1}\right)\end{array}$ \\
\hline \multirow{3}{*}{$01 / 18$} & Root & GTAW & ER80S-Ni1 & 1.2 & DCEN & $160 \sim 180$ & $11 \sim 12$ & $75 \sim 120$ & $12 \sim 15$ \\
\hline & Hot & FCAW & E81T1-K2C & 1.2 & DCEP & $160 \sim 190$ & $24 \sim 26$ & $160 \sim 200$ & $20 \sim 25$ \\
\hline & Fill, Cap & FCAW & E81T1-K2C & 1.2 & DCEP & $165 \sim 185$ & $24 \sim 26$ & $200 \sim 220$ & $20 \sim 25$ \\
\hline \multirow[b]{2}{*}{$02 / 03$} & Root & GTAW & ER80S-Ni1 & 1.2 & DCEN & 176 & 13 & $72 \sim 110$ & $12 \sim 15$ \\
\hline & Hot & GTAW & ER80S-Ni1 & 1.2 & DCEN & 191 & 13 & $91 \sim 93$ & $12 \sim 15$ \\
\hline
\end{tabular}

\subsubsection{Stainless Steel Piping}

The temperature design of stainless steel process piping is $-50,-104$ and $-196^{\circ} \mathrm{C}$, respectively. The temperature of welding procedure qualification is $-196^{\circ} \mathrm{C}$. The welding consumables are KT-308L/KM-308L (ER308L). The ferrite number of welding wire is behind $7 \mathrm{FN}$. The lateral expansion of weld metal must exceed the $0.38 \mathrm{~mm}$ at $-196^{\circ} \mathrm{C}$. The design and parameter of welding procedure qualification for stainless steel is shown in Table 5 and Table 6, respectively.

Table 5. Design of welding procedure qualification for austenite stainless steel (304L).

\begin{tabular}{lllll}
\hline WPS No. & Thickness of piping $(\mathbf{m m})$ & Groove & Welding process & Welding consumables \\
\hline 01 & 10.31 & V type & GTAW/GMAW & ER308L \\
18 & 19.05 & V type & GTAW/SAW & ER308L \\
\hline
\end{tabular}

Table 6. Welding parameters for austenite stainless steel.

\begin{tabular}{|c|c|c|c|c|c|c|c|c|c|}
\hline WPS. No. & Pass & $\begin{array}{l}\text { Welding } \\
\text { process }\end{array}$ & $\begin{array}{l}\text { Welding } \\
\text { consumables }\end{array}$ & $\begin{array}{l}\text { Wire size } \\
(\mathrm{mm})\end{array}$ & Polarity & Current (A) & Voltage (V) & $\begin{array}{l}\text { Speed } \\
\left(\mathrm{mm} \cdot \mathrm{min}^{-1}\right)\end{array}$ & $\begin{array}{l}\text { Gas } \\
\text { flow }\left(L \cdot \min ^{-1}\right)\end{array}$ \\
\hline \multirow{2}{*}{01} & Root, Hot & GTAW & ER308L & 1.2 & DCEN & $171 \sim 180$ & $12 \sim 13$ & $75 \sim 130$ & $12 \sim 18$ \\
\hline & Fill, Cap & GMAW & ER308L & 1.2 & DCEP & $180 \sim 190$ & $25 \sim 28$ & $125 \sim 133$ & $20 \sim 25$ \\
\hline \multirow{2}{*}{18} & Root, Hot & GTAW & ER308L & 1.2 & DCEN & $142 \sim 198$ & $11 \sim 14$ & $78 \sim 120$ & $15 \sim 20$ \\
\hline & Fill, Cap & SAW & ER308L & 2.4 & DCEP & $270 \sim 330$ & $27 \sim 32$ & $320 \sim 404$ & -- \\
\hline
\end{tabular}

Welding parameters of PWPS (preliminary/pre-qualified welding procedure specification) consist on welding current, wire feeding speed, welding speed, oscillation frequency, oscillation width and dwell time, as shown in Figure 1 (a). 
The position of torch is shown in Figure 1(b).

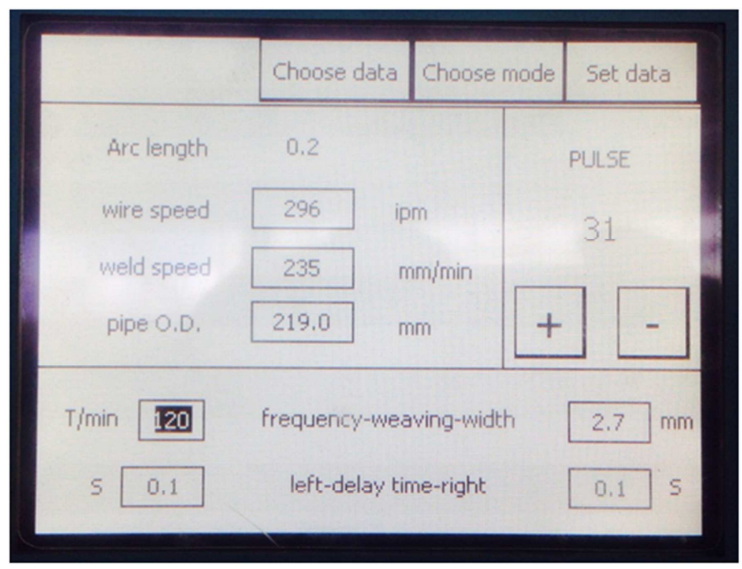

(a)

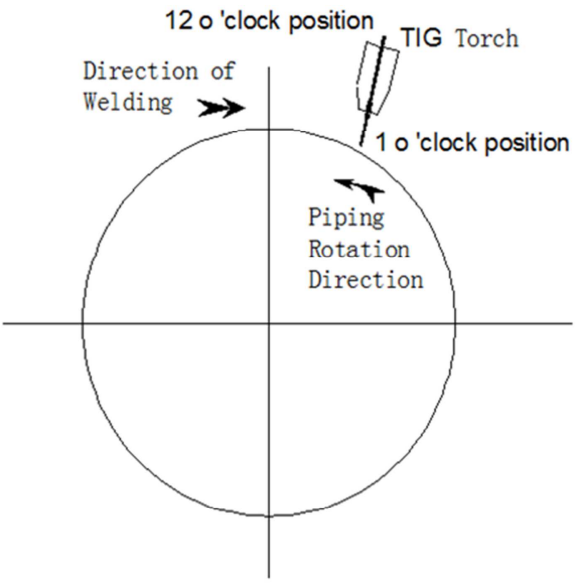

(b)

Figure 1. Welding setting of PWPS (a) Welding parameters; (b) position of welding torch.

\subsection{Mechanical Properties of Weld Metal}

The mechanical properties of low temperature carbon steel piping and austenitic stainless steel piping are shown in Table 7 and Table 8 , respectively.

Table 7. Mechanical properties of carbon steel piping.

\begin{tabular}{|c|c|c|c|c|c|c|c|}
\hline \multirow{3}{*}{ WPS. No. } & \multirow{3}{*}{ T.S./MPa } & \multirow{3}{*}{ Bending test } & \multicolumn{5}{|l|}{ Impact test } \\
\hline & & & \multirow{2}{*}{$\begin{array}{l}\text { Dimension of specimen } \\
(\mathrm{mm})\end{array}$} & \multirow{2}{*}{$\begin{array}{l}\text { Testing temperature } \\
\left({ }^{\circ} \mathrm{C}\right)\end{array}$} & \multicolumn{3}{|c|}{ Toughness (J) } \\
\hline & & & & & Weld metal & HAZ near piping & HAZ of forging \\
\hline 01 & $637 / 540$ & Pass & $8 \times 10 \times 55$ & -50 & $104,81,145$ & $127,162,155$ & $84,94,79$ \\
\hline 18 & $591 / 611$ & Pass & $4 \times 10 \times 55$ & -66.7 & $30,33,58$ & $19,27,26$ & $22,25,22$ \\
\hline 02 & $585 / 590$ & Pass & $8 \times 10 \times 55$ & -50 & $94,104,130$ & $104,149,120$ & $114,75,82$ \\
\hline 03 & $538 / 539$ & Pass & $8 \times 10 \times 55$ & -50 & $89,115,135$ & $126,122,149$ & $117,106,114$ \\
\hline
\end{tabular}

Table 8. Mechanical properties of austenitic stainless steel piping.

\begin{tabular}{|c|c|c|c|c|c|c|c|c|c|}
\hline \multirow{3}{*}{ WPS No. } & \multirow{3}{*}{ T.S./MPa } & \multirow{3}{*}{$\begin{array}{l}\text { Bending } \\
\text { test }\end{array}$} & \multicolumn{4}{|l|}{ Impact test } & \multicolumn{2}{|c|}{ Lateral expansion (mm) } & \multirow{3}{*}{$\mathbf{F N}$} \\
\hline & & & \multirow{2}{*}{$\begin{array}{l}\text { Dimension of } \\
\text { specimen }(\mathrm{mm})\end{array}$} & \multirow{2}{*}{$\begin{array}{l}\text { Testing } \\
\text { temperature }\left({ }^{\circ} \mathrm{C}\right)\end{array}$} & \multicolumn{2}{|c|}{ Toughness (J) } & \multirow{2}{*}{ Weld metal } & \multirow{2}{*}{ HAZ } & \\
\hline & & & & & Weld metal & HAZ & & & \\
\hline 01 & $626 / 631$ & Pass & $8 \times 10 \times 55$ & -196 & $77,74,79$ & $176,87,117$ & $1.0,1.0,0.875$ & $1.65,1.47,1.72$ & 4.3 \\
\hline 18 & $633 / 630$ & Pass & $10 \times 10 \times 55$ & -196 & $34,39,38$ & $78,100,78$ & $0.45,0.45,0.55$ & $1.10,1.35,0.95$ & 6.3 \\
\hline
\end{tabular}

\subsection{Appearance of Weld Metal}

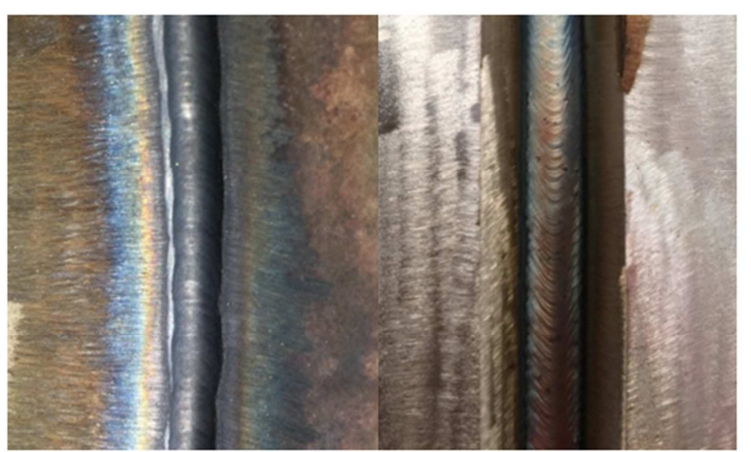

(a)

(b)

is perfect. The fusion of groove is good. The weld metal is inspected by X-ray and magnetic particle inspection. There is no incomplete root fusion and surface defect, as shown in Figure 2 and Figure 3, respectively.

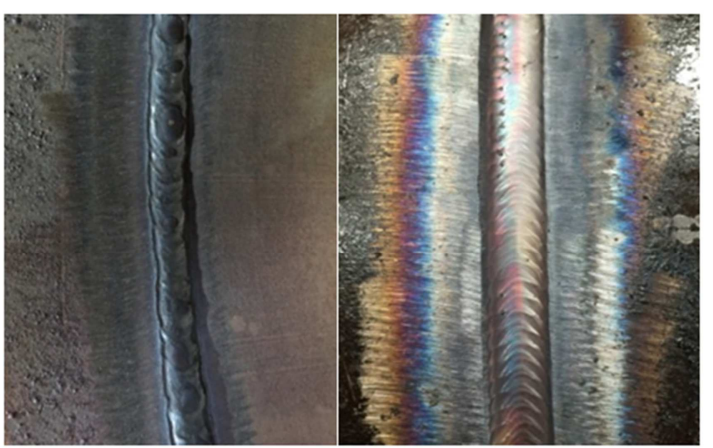

(a)

(b) the root pass; (b) bead shape in the groove.

The appearance of weld metal by automatic TIG welding is good. Especially, the shape of reverse side of the root pass

Figure 3. Bead shape of low temperature carbon steel piping: (a) reverse side of the root pass; (b) bead shape in the groove. 


\subsection{Mechanical Properties}

The welding process evaluation of low temperature carbon steel shows that the mechanical properties meet the requirement of Yamal project. Figure 4 shows the microstructure of KM-80Ni1 and KFX-81K2. IIW provides

"Guidelines for the Classification of Ferrite Steel Weld Metal Microstructural Constituents Using the Light Microscope" [7] to analyze the type of ferrite in low carbon steel weld metal. There are 3 type ferrite, such as primary ferrite (PF), ferrite with secondary phase (FS) and acicular ferrite (AF). Figure 4 indicates there are PF, FS and AF in the weld metal of KM-80Ni1 and KFX-81K2. The content of acicular ferrite is the most. H. K. D. H. Bhadeshia [8] presents that the morphology of ferrite is changed by adding alloy element in weld metal. Dolby [9], Glover [10] and Onsoien [11] indicate the formation of acicular ferrite improves the toughness in low temperature. Therefore, appropriate $\mathrm{Ni}$ element in the weld metal of KM-81Ni1 and KFX-81K2 makes the excellent toughness in low toughness.

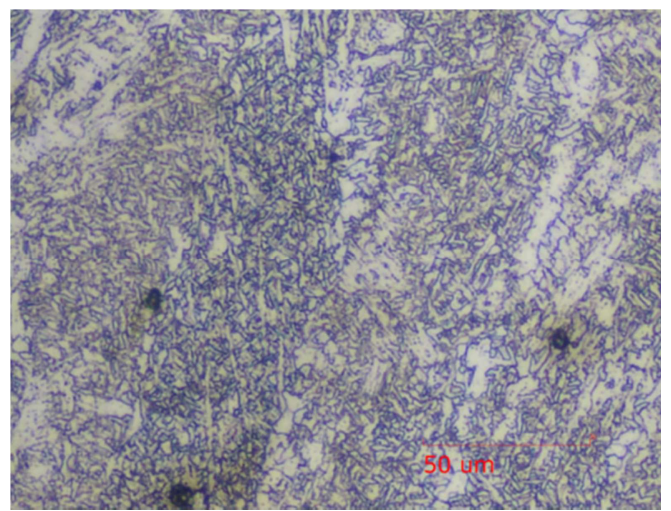

(a)

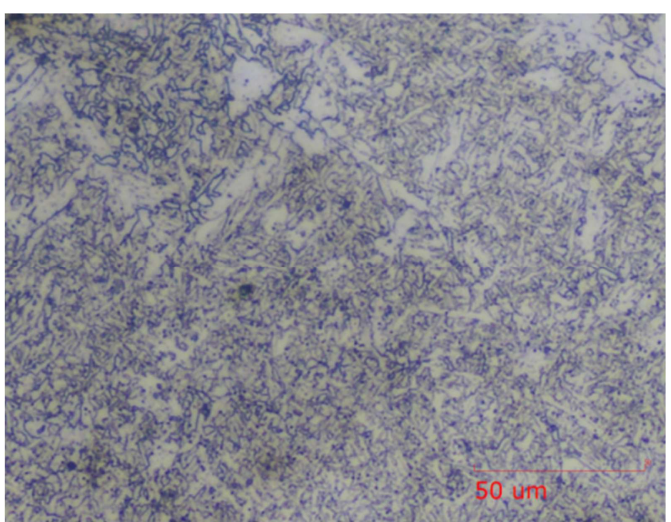

(b)

Figure 4. Microstructure of weld metal for low temperature carbon steel: (a) KM-80Ni1; (b) KFX-81K2.

The welding process evaluation of austenitic stainless steel shows that the mechanical properties meet the requirement of Yamal project, such as above $0.38 \mathrm{~mm}$ of the lateral expansion at $-196^{\circ} \mathrm{C}$. The ferrite number of stainless steel weld metal is behind 7FN and meets the requirement of ferrite number in cryogenic piping. It ensures the toughness of austenitic stainless steel in cryogenic environment. Figure 5 shows the microstructure of KM-308L. The microstructure of austenitic stainless steel is massive austenite and tiny ferrite. The grain size of austenite is small. The study of Graham Holloway [12] presents that the welding consumables in $-196^{\circ} \mathrm{C}$ environment should select the $\mathrm{CF}$ (Controlled ferrite) stainless steel. CF stainless steel guarantees the lateral expansion is above $0.38 \mathrm{~mm}$. The ferrite number of $\mathrm{CF}$ stainless is behind $7 \mathrm{FN}$ to ensure the toughness in cryogenic environment.

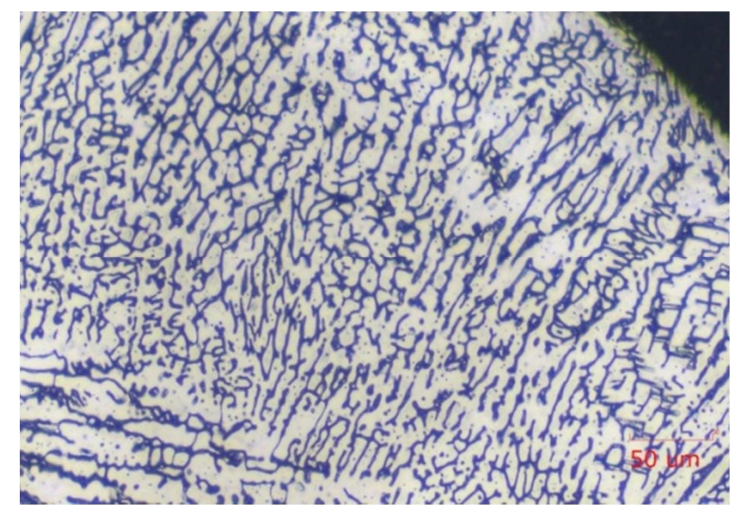

Figure 5. Microstructure of weld metal for austenite stainless steel (KM-308L).

\section{Advantages of Automatic TIG Welding}

The advantages of automatic TIG welding are shown as following:

(1) Excellent appearance and shape of weld metal: especially in double-side formation with one-side welding.

(2) Welding efficiency

The speed of automatic root pass welding for austenitic stainless steel and low temperature carbon steel is above 70 $\mathrm{mm} / \mathrm{min}$. The speed of manual root pass welding is between 30 and $45 \mathrm{~mm} / \mathrm{min}$. The speed of automatic hot pass welding is above $110 \mathrm{~mm} / \mathrm{min}$. The speed of manual hot pass welding is $70 \mathrm{~mm} / \mathrm{min}$. The melting rates of base metal and filler which are determined by heat input and welding efficiency influence welding product efficiency [13]. The welding current of automatic welding is higher than that of manual welding. The thickness of weld metal for automatic root pass and hot pass welding is above $5 \mathrm{~mm}$. The thickness of weld metal for manual root pass and hot pass welding is between 3.5 and $4 \mathrm{~mm}$. The weld metal with $4 \mathrm{~mm}$ thickness is able to meet the requirement for GMAW or FCAW. However, the weld metal with $4 \mathrm{~mm}$ thickness is not enough for SAW. The additional hot pass is essential to avoid to burn through. Therefore, the efficiency of automatic TIG welding is 3 times higher than that of manual TIG welding.

(3) Performance of weld metal.

The welding speed of automatic TIG welding is 1 time higher than that of manual TIG welding. Although the welding current of automatic TIG welding is higher than that of manual TIG welding, the heat input is constant. The impact toughness at low temperature meets the requirement 
of $27 \mathrm{~J} \mathrm{min.} \mathrm{The} \mathrm{intergranular} \mathrm{corrosion} \mathrm{resistance} \mathrm{of}$ austenitic stainless steel with automatic TIG welding is not deteriorated.

\section{Conclusion}

The automatic TIG welding is successfully applied in the fabrication of YAMAL LNG Project. It is important to select appropriate welding process, welding consumables and welding parameters. The automatic TIG welding produces the excellent appearance and shape of weld metal in root pass and hot pass. Good shape and appearance of weld metal is better for reducing internal fluid resistance of process piping. It can help enhance the velocity of flow. The welding efficiency of automatic TIG welding is 2 times higher than that of manual TIG welding. This automatic welding process ensures the toughness at low temperature of low temperature carbon steel and austenitic stainless steel. It also guarantees the intergranular corrosion resistance of austenitic stainless steel.

\section{References}

[1] Job specification: Welding \& NDE of Piping Shop and Field. Document No: 3300-E-000-MC-SPE-63002-00-D.

[2] T. Ogawa and E. Tsunetomi, Hot cracking susceptibility of austenitic stainless steels, Welding Journal, 1982, 61, 82s-93s.

[3] A. Zingales, G. Quartarone, and G. Moretti, Sigma phase intergranular corrosion effects in austenitic welds containing ferrite, Corrosion, 1985, 41, 136-141.

[4] J. Muraleedharan, B. Gnanamoorthy, and P. Rodriguez,
Comparative study: degree of sensitization and intergranular stress corrosion cracking susceptibility of type 304 stainless steel, Corrosion, 1996, 52, 790-800.

[5] Z. Stonawska, M. Svoboda, M. Sozanska, M. Kristková, J. Sojka, C. Dagbert, and L. Hyspecka, Structural analysis and intergranular corrosion tests of AISI 316L steel, J. Microsc., 2006, 224, 62-64.

[6] M. Terada, M. Saiki, I. Costa, and A. F. Padilha, Microstructure and intergranular corrosion of the austenitic stainless steel, J. Nucl. Mater, 2006, 358, 40-46.

[7] IIW, Guidelines for the Classification of Ferrite Steel Weld Metal Microstructural Constituents Using the Light Microscope, v Welding in the World, 1986, 24, 144-148.

[8] H. K. D. H. Bhadeshia and L. E. Svensson, Mathematical Modelling of Weld Phenomena, Eds. H. Cerjak and K. Easterling, Institute of Materials, 1993.

[9] R. E. Dolby, Research Report No. 14/1976/M, Welding Institute, Cambridge 1976.

[10] A. G. Glover, J. T. McGrath and N. F. Eaton, Toughness Characterization and Specifications for HSLA and Structural Steels, ed. P. L. Manganon, Metallurgical Society of AIME, NY, 143-160.

[11] M. I. Onsoien, S. Liu and D. L. Olson, Shielding Gas Oxygen Equivalent in Weld Metal Microstructure Optimization, Weld. J., 1996, 64, 216s-224s.

[12] G. Holloway and A. Marshall, Ultra-low Temperature Welding and Welding Materials for Liquefied Natural Gas, Mechanic Worker, 2005, 8, 35-40.

[13] Welding Manual (Materials) Volume 2, Edition of China Institute of Mechanical Engineering Welding Society (2nd) Machinery Industry Press, Beijing, 2001, 3. 